\title{
Transformation of Family Law in the First Third of the Twentieth Century
}

\author{
Mikhail D. Severyanov** and Larisa U. Anisimovab \\ ${ }^{a}$ Siberian Federal University \\ 79 Svobodny, Krasnoyarsk, 660041, Russia \\ ${ }^{b}$ Russian State Social University (Branch in Krasnoyarsk) \\ 11 Mozhaiskogo Str., Krasnoyarsk, 660041, Russia
}

Received 18.07.2014, received in revised form 12.08.2014, accepted 29.08.2014

Russian and foreign historiography discuss the question on whether there was a sexual revolution in Russia in 1917-1922 and in the USSR in 1923-1927. In the article the authors define a concept of "sexual revolution", consider opposing views on the issue and carry out an analysis of the legislative base, discussions of the period of the 20th and modern literature. As a result the authors concluded that 1917-1927 is an independent period in historiography of the problem. The legislative base was liberalization, emancipation of women; however, women still were in economic dependence on men. Numerous discussions, publications of those years partially reflected life of youth, especially student life in the large cities. In rural areas, family and marriage were still based on a patriarchal family structure.

Keywords: legislation, legislative base of a family and marriage, sexual revolution, emancipation of women.

Research area: History.

\section{Introduction}

Was there a sexual revolution?

In the framework of socio-cultural experiments that began in Russia in 1917, after the Bolsheviks came to power, the important place was taken by the process of transformation of family relations. However, the transformation of interpersonal relations between men and women has not yet received an unambiguous assessment as in both Russian and foreign historical sciences. In literature the following problems are discussed: was there a sexual revolution in the RSFSR in the 1917- 1920's? Was sexual culture a continuation of traditional, "originally" Russian sexual value or its denial?

We will try to sort out this problem. In its analysis, on the one hand, it is necessary to address a conceptual apparatus of defining a sexual revolution, which is still not clearly defined, and on the other hand, to analyze and compare the tsarist and Soviet legislation, numerous articles, speeches, publications of the party and government functionaries, publicists, researchers, materials of sociological polls and other historical sources.

(C) Siberian Federal University. All rights reserved

* Corresponding author E-mail address: severyanova@mail.ru 
One of the first attempts to define a sexual revolution was made by $\mathrm{P}$. Sorokin at the early $20^{\text {th }}$ century, i.e. before revolutionary overthrows. $\mathrm{He}$ described its features as follows: increase in the number of divorces and abortions, family breakdowns, increase in the number of childless families; increasing sexual promiscuity, uncontrolled sexual behaviour, growing desire for sex; cultural sexualisation; change of the content of such important fundamental institutes of society as marriage and family, birth and death rates, moral principles of society (P. Sorokin, 2006). W. Reich considers that a sexual revolution is a process and a result of basic changes in the sexual life of a society, characterized by transformation of sexual values, orientations, norms, sanctions and sexual relations liberating a personality and a society, levelling public moral norms prohibiting sex outside of marriage, chastity and others (W. Reich, 1986).

\section{Patriarchal and Christian family pattern}

The tsarist legislation gives a clear answer to a question of sexual economy based on authoritative morals of sexual oppression, which does not does not allow us to talk about real freedom of women. Let us quote an excerpt from the tsarist legislation: Art.106 of the Civil Code determined husband's attitude towards wife: "A husband shall love his wife as his own body and live with her in harmony; he shall respect and protect her, forgive her shortcomings, and bear her infirmities. He shall provide his wife with livelihood and support to the best of his ability". The Article 107 of the Civil Code determined a wife's status in a family: "A wife shall obey her husband as a head of the family, treat him with love, respect and unlimited obedience and render him gratification and attachment as a hostess of the house. When a husband moves somewhere, a wife has to follow him; without permission of a husband a wife cannot be employed". A family life of a woman had to correspond with the inner religious meaning. Marriage was executed through the church wedding. It was forbidden to marry without consent of parents, guardians or trustees, and for persons of public service - without permission of administration on service (Art. 6 and Art. 9, V.10, P.1 of the Code of Laws of the Russian Empire). Marriage could only be dissolved by a spiritual court at the request of one of spouses: in case of the proved adultery of the other spouse or his/her inability to marital cohabitation. A suit for divorce could be initiated only after three years of marriage: if one spouse was convicted of a crime involving disfranchisement or exiled to Siberia, in case of unexplained and prolonged absence of another spouse (Article 45). Unauthorized divorce without court, under just mutual agreement of spouses was not allowed. Marital law also strictly forbade any act that could lead to the separation of spouses. Spouse's admission of violation of the sanctity of marriage by adultery would not be accepted as evidence if it was not consistent with the facts of the case and was not accompanied by evidence supporting it.

Spiritual foundations of marriage, family and relationships between spouses, parents and children were professed by Christianity. In the Christian religion childbearing was considered as the justification of carnal principle of marriage, which was seen as the highest meaning of marriage. The very marriage was under the blessing of the church. The Christian Church was extremely resistant to any types of divorce and birth control. Family law for population had religious and mystical character. Failure to comply with the norms of family law puts, for example, the peasant under condemnation by the villagers. A peasant brought up in the spirit of Orthodoxy, understood marriage primarily as a moral obligation and a pledge of wealth 
and social prestige. All that was sanctified by providence had an exceptional value in Russia: "Children are the blessing of God and express the presence of the Holy Spirit in the family, they are support and happiness of family" - this was the prevailing view on children. Children created not only the internal strength of a family principle and contained an instinctive desire to procreate, but also consciousness of the importance of succession of labour in every generation: to work for children as their future successors.

Parenting was directed to teach children the rules of faith. In order to correct children who were disobedient to them, parents had the right to use domestic educational measures, and in case of failure of these means they were imperious to imprison them for a period of 2-4 months and more for stubborn disobedience to a parental will, dissolute life and other violations. Parents had to pay all their attention on the moral education of their children. Children were expected to provide parents a sincere reverence, obedience, humility and love (articles 164, 165).

Thus, the rigid marriage law served as a protection of the weak, first of all children. It disciplined men by consciousness of their responsibility for wellbeing of a family. According to the "New Testament" adultery was admitted as the most grievous sin because it could not exist without lie to a spouse, children, parents. The law was directed at honouring seniors, first of all, a father.

The law provided connection of parents' and grandparents' mind to a choice of a spouse, because the youth, when a choosing a partner in life, often is guided by a sexual inclination, is inexperienced, decides their destiny at first sight. Parents looked through the second and third generation. And if someone was a thief, a drunkard or a fool, nobody wanted to become related with his children and grandsons, which strongly disciplined people.
In the conditions of domination of religious views of values in a family, children were brought up in the spirit of obligatory marriage. Children were of considerable value. High birth rate of the population testified to the absence of the practice of birth control. The consciousness of most people virtually ruled out any intervention in physiological processes, and any attempts to prevent pregnancy or abortion were categorically condemned by the church. Peasant women did not practice abortions, and the vast majority of them did not even know about it. Most of the peasants considered the expulsion of the fetus as a grave sin, and many saw a debauch of young generation in it. A village public opinion was extremely strict with the girls who committed this offense. A girl who gave birth to a child was much more likely to get married than the one who had a miscarriage.

Let us note that Orthodox Christianity like other religions and secular authorities always constrained a woman by restriction in the rights, rules and worldly talks due to her specifics. In fact, it was the actual equality, because it was considered that women with the means given to them by the nature and, thanks to the place in a family, without the rights actually have the greater rights. F.M. Dostoyevsky considered that Christianity gave equality to the woman ("The Diary of the Writer"). A scientist A.N. Engelhardt came to a similar conclusion in the $19^{\text {th }}$ century in the well-known "Twelve Letters from the Village". Restriction and even severity concerning women were entered in a family on the basis of world experience of the peoples. In all world religions it is considered, only those people are viable who follow such rules.

Thus, before revolution a Russian family represented a traditional type of the family organization, differed by a authoritative structure, full submission of a wife to her husband, obedience of children to parents. The family was 
a small community of a quite self-sufficient type. The family and its labour economy functioned at the same time and as the main unit of biological reproduction, and as a unit of property, production and consumption.

According to its contents, the imperial legislation fixed the power of a husband and a father, his right, and impossibility of existence of economy out of a family. According to W. Reich, moral regulation of sexual relations was expressed in that spouses were under duress of the moral obligation fixed by the law. A husband should love his wife whether he can or not, and later - whether he wants it or not. A wife had to be submissive housewife. A change of the situation that became hopeless was impossible. The law directly obliged parents to use their power over children in precisely those purposes that are absolutely united with interests of the authoritative government, such as for the stubborn defiance of parental authority (representative of the state authorities) could put children in prison from 2 to 4 months.

Radical changes in the legislation on marriage and family

Since December 1917, the communist legislation was based on a different ideological basis. It was based on the work of Friedrich Engels "The Origin of the Family, Private Property and the State": patriarchy marked the beginning of the division of society into social classes (men masters, women - slaves). A family allegedly for a woman deprived of civil rights became prison, from which she should be released. Based on this postulate, the Marxism-Leninism began to build the program for ensuring 'equality' of women. Not by chance did an American researcher Ch. Tomas Phillips describe Marxism in this part as one of the directions of feminism that ignited in a government program, first in Russia (after October 1917), and later by its example in other countries (Ch. Tomas Phillips, 2002).
In the first months of its existence, the communist authorities decrees "On a civil marriage, on children and on maintaining books of Acts of Civil Status" (December 18, 1917) "On divorce" (December 29, 1917), "On illegitimate children" (December 20, 1917) made some kind of revolution in the field of legislation on marriage and family. So, before the revolution, religious and legal intolerance created an atmosphere of contempt ignoring illegitimate children. At the Soviet power the equal rights for marriage and illegitimate children were established. At the First All-Russian Congress of Female Workers held on November 19, 1918 V.I. Lenin spoke: "We issued a decree ("On illegitimate children" - A.L.) that destroyed a difference in position of a marriage and an illegitimate child", thereby realize the equality and freedom of women giving them the right to sue the children's father for their support. These decrees, as well as the "Code of laws on civil status, marriage, family and guardianship law" (1918) formed entirely on their basis, defined the basic position of the Soviet power in the field of marriage and family law. First of all, the Code recognized the only lawful form of marriage - a civil marriage registered in government bodies, an actual cohabitation was not considered as marriage. Marriage appeared as a free union, any coercion to marriage was considered unacceptable. Intending spouses before the declaration of accession to marriage had to present a subscription about voluntary marriage and about lack of obstacles to marriage. People who reached lawful age could get married (for women -16 years old, for men -18 years old). A marriage was considered invalid if spouses or one of them did not reach a marriageable age, except for the following cases: a) when proceedings on invalidity of marriage were initiated after occurrence of marriageable age, or b) when a marriage was followed by the birth of children or pregnancy of wife. Impediments to marriage were: 
a) registered or unregistered marriage; b) mental illness; c) close relations (brothers and sisters, including illegitimate relationship). Marriage to under-aged persons entailed imprisonment for up to 2 years; compulsion of a woman to marriage or coercion to continuation of marital cohabitation was considered as a criminal offense and was punished by imprisonment for a period of up to 2 years; in the case of contamination of their husband or wife with a venereal disease a perpetrator was punished by imprisonment of up to 3 years (A. Gence, 1929). Freedom of divorce was declared. The divorce process was greatly simplified. Grounds for divorce could be a mutual consent of both spouses, or a desire of one of them to divorce.

The adopted laws eliminated all previous bans: social, national, religious. Legislation proclaimed secularization of marriage and the removal of all civil cases of marriage and divorce from the jurisdiction of church bodies ("On freedom of conscience and separation of church from the state", dated January 20, 1918). On July 20, 1919 the newspaper "Soviet Siberia" wrote that the central spiritual institutions and spiritual consistory began receiving petitions for divorce, according to the new law. Let us note that the communistic power did not allow church wedding ceremony, it was a private affair of spouses considered as the illegal act. The church marriage contracted before December 20, 1917, was not forbidden and was considered as the registered marriage. The church marriages concluded after December 20, 1917 in districts temporarily being under the power of the white were admitted. Thus, the NKU (National Commissariat of Justice RSFSR) under the agreement with the NKVD (People's Commissariat for Internal Affairs) in a modified Circular published in the "Bulletin of the PCIA" No. 15-16 dated May 13, 1924, noted: a) in districts in which the Soviet power was established after this term (December 20, 1917 - L.A.) until the formation of Councils and the actual beginning of registration of marriages by the civil order; b) in districts where registry offices temporarily stopped the activities during occupation of these districts by the white - until restoration of their activity. In Siberia these laws operated in districts: Achinsk, Kansk, Krasnoyarsk, Minusinsk, Khakassia - till February 12, 1920, in the Irkutsk province - till March 27, 1920 (S.S. Tizanova, 1926).

New laws, unlike the imperial legislation, fixed an equal position of spouses: the equality of the spouses to choose their occupation, change of residence, acquired property together, legacy of the property of each other, their nationality, their name, a casting vote in the education of children and etc. As you can see, the Soviet legislation weakened influence of church on a family, guaranteed to a woman participation of the father in the maintenance of children, to some extent limited the frivolous connections, interfered with monogamy violation, allowed to divide property when getting divorced.

In the decree on secularization of marriage a woman on par with a man received a right to land, property disposal yard, to inherit and participate in family repartitions with receiving a share. The most important consequence of the decree on the land and the law on socialization of the land (1918) was legal elimination of the main economic prerequisite of dependency of a woman. The equalization of rights of all members of economy led to restriction of the power of a householder. The new code equated work of women in a household and a care for children to work of men in the social production; and defined an order of collection of the alimony.

On November 18, 1920 abortion was legalized in medical institutions and forbidden in private practice on November 18, 1920. The Soviet Russia became the first-ever state in which 
it was authorized to families to plan a childbearing (No. 90 SU. Art. 471).

1926 became a milestone in the development of the family legislation. This year the new Code of Laws on Marriage, Family and Guardianship was adopted. The main change was that this Code recognized common marriages legal, i.e. cohabitation. Common marriage spouses received equal rights to marital property, alimony from the other spouse as a result of disability, for the help and even pension in case of death of one of spouses, etc. The evidence of cohabitation was a joint household, mutual financial support, parenting, etc. By the law, it was enough to identify the marital relationship to third parties, in personal correspondence and other documents. Code of the RSFSR (1926) recognized only serious and lasting relations aiming at creation of a family as the common marriages. The French lawyers designated a peculiar attitude as "a free union without marriage" (A.V. Makletsov, 1937). According to A.V. Makletsov, attempts of the Soviet lawyers to establish distinct differences between the casual relationship and the common marriage were vain. Recognition of the actual marriage by the law caused complication of the property relations between spouses. The Soviet jurisprudence recognized that the common wife had the right to inherit the property of the person with whom she was in common marriage relationship, though heir and was simultaneously registered marriage (Definition of the Supreme Court of RSFSR. Jurisprudence. 1927. No. 19). In the case of establishing that by the day of death the heir had two common marriages, both of his wives had the right to inherit his property (Judicial practice.1929. No. 16). According to the Article 2 of the Code on Marriage, Family and Guardianship, property acquired by the spouses during the marriage was considered as community property of spouses and persons in common marital relationship. At discussion of the draft of the new Code its opponents feared that the identification of the common marriage would mean the registered declaration of freedom debauchery, legalize polygamy and polyandry, and it was really so. In 1923 the Head of the Department of Female Workers of the RCP(b) P. Vinogradskaya wrote about "polyandry" and "polygamy" manifestations at the highest levels of the party as about quite an admissible practice. For part of communists simplification under the decree on divorce dated 1917 and the idea of sexual revolution became convenient. The Pravda newspaper dated May 7, 1925 stated: "Communists perceive the terms 'husband', 'wife' as the bourgeois invention. They get shocked when they get asked about their wives. In reply they ask a question: 'Which one of them?"' (M.Stern, 1981). "Izvestia" dated December 23, 1926 reported that in Moscow population census of 1926 found a considerable number of common polyandry (polygamy). Archival materials indicate cases of polygamy in Siberia. So, in 1927 in the Achinsk district the secretary of the Tyukhtetsk committee of All-Union Communist Party (Bolsheviks) "had the whole harem of servants, mainly local prostitutes who at the same time were his wives".

In 1925-26 during the heated debate on the new Code of Marriage and Family, peasants, especially the elderly, spoke about improving the divorce proceedings, the undesirability of crushing the peasant economy, suggested the alimony to determine from peasants only by a share of the respondent on products and the monetary income of economy. The code of 1926 excluded possibility of collecting the alimony from several individuals. It obliged the court to recognize in these cases one person as a father and to confer responsibility on it. The Code repealed alimony rights and responsibilities between brothers and sisters. Alimony obligation remained only between parents and children. By 
law (1918) even parents had the right of alimony from children, and brothers and sisters, except for children, if they needed them or in case of disability.

The new Code came into force since January 1, 1927 and legalized all those radical innovations to which representatives of the country population, first of all, so-called common marriage and divorce according to the unilateral statement of one of the spouses especially objected. Marriageable age was raised to 18 years for men and women. Thus, the family law was brought in line with the legislation of the RSFSR. Besides the "The Code of the law on marriage, family and guardianship" also introduced new institution of the family law, adoption, which was a kind of admission of a strange as a member of the peasant household. Authors of the Code of 1918 considered that institute of adoption became obsolete, which allegedly contradicted the principles of communism. During an era of broad expansion of a network of establishments of social education and providing this institute was represented unnecessary since the adoption could be used for the purpose of economic exploitation of children. The commissioner of justice D.I. Kurskiy wrote justifying adoption: "We allowed adoption that was forbidden by the former Code as we thought that the state itself can maintain and educate orphans. Experience has shown that we cannot carry out public care of children in need". Art. 48 of the new Code proclaimed that adoption is allowed only in interests of children. When adopting children aged more than 10 their consent was required. Those adopted in relation to the adoptive parents and adoptive parents in relation to the adopted children by all rights were equated with relatives by birth. According to the Soviet press, this measure was carried out unsuccessfully. In newspapers there were reports on trials on torture of the adopted children, especially those who were morally defective and spoiled, placed in families of peasants and handicraftsmen forcibly, against their will.

\section{Conclusion}

The problem on whether there was a sexual revolution in the Soviet Russia in 1917-1922 and in the USSR in 1923-1927 has been debated from the moment of emergence of acts of marriage and family during a considered period. In those years, outlined two radically opposing judgments on this issue, which are present in both Russian and foreign modern literature.

Supporters of the point of view that in Russia sexual revolution was carried out are P. Sorokin, W. Reich, O. Greyg and other researchers. They operate mainly with sociological polls among students, behavior of a part of Komsomol members, workers and communists, assessment of legislative acts, literary works of those years.

Supporters of the other, conservative, point of view although noted progressive value of legislation in the emancipation of women, also like V.I. Lenin considered that the legislation became only the beginning in the formation of the new in a family and marriage, sexual relations. Conservatives had all the treasure of old arguments and "evidence", which suggest that by the time the Bolsheviks came to power they had no programmes in the field of family relations. Discussions testify to it in Communist party concerning party ethics, E.I. Kviring, E.A. Preobrazhensky, L.D. Trotsky's publications, S. Smidovich, A.M. Kollontai, A.Zalkind, A. Nemilov, N. Semashko and others. A distinctive feature of their publications was the fact that they paid a great attention to solving "a sexual question" to further strengthen the new government.

In those years, Western conservatives met Bolshevik attempts to reform the institution of marriage and family with anger and anxiety, even fear. The irony was that both radicals 
and conservatives argued adducing the same arguments: to protect women from being treated as property (Lewis.H. Siegelbaum, 1992; S. Solomon, 1922; V.F. Calverton, 1928; M. Hindus, 1929; G. Carleton, 2005). If for the left radicals this meant deliverance from a patriarchal system, for the right ones it meant defense against women becoming a "nationalized" resource of the state, that is, possessions for men's pleasure.

To this day remains controversial among researchers periodization of the revolutionary legislation of those years. So, for example, I. Kon considers that in 1917-1930 there was a disorganization of traditional matrimonial way; social emancipation of women; weakening of the institute of marriage and the sexual morals based on it; a sharp increase in number of abortions, growth of prostitution, venereal diseases; standard uncertainty and debate concerning sexuality (Kon, 1997). A.M. Strakhov considers that the first sexual revolution came to the end with establishment of a totalitarian regime in the USSR (A.M. Strakhov, M.V. Rabzhayeva, A.V. Vereshchagina).

Part of researchers with whom the authors of the article agree, in the family policy of the Soviet state allocate 1917 -mid-20s of the $20^{\text {th }}$ century, which was characterized by liberalization of the family law and the legitimization of a number of the individual rights and freedom forbidden in pre-revolutionary Russia. At the same time, progressiveness of the legislation in many respects was declarative as a woman at all rights, opportunities and equality remained economically dependent on a man.

The code on marriage, family and guardianship of 1926 was, on the one hand, the state recognition about the insolvency of nationalization of a number of family functions, and on the other hand, transferred a number of functions on upbringing children to a family, and after divorce - to women.

Thus, in 1917-1926 was mainly the period of creation of the state and legal base for formation of a new family way. The bulk of the population (peasants) in the RSFSR (more than 100 million from 146 million inhabitants) adhered to the Christian patriarchal way. So, according to A.V. Makletsov, in 1926-1927 in rural areas of Russia $10 \%$ of marriages were conducted without church ceremony, only in some areas this rate rose to $25 \%$ (A.V. Makletsov, 1937), which disproves the version about sexual revolution in the RSFSR in 1917-1927.

\section{References}

1. Calverton V.F., The Bankruptcy of Marriage. New York. Macaulay Co., 1928, p. 33-59.

2. Carleton G. Sexual Revolution in Bolshevik Russia. (Pittsburgh: University of Pittsburgh Press, 2005, p. 1-18.

3. Children's homelessness and the children's house. Under the editorship of S.S. Tizanova, etc., M., 1926, p. 59.

4. Gence A. Abortion problem in the USSR. Gosmedizdat. 1929, p. 60.

5. Hindus Mourice, Humanity Uprooted. N.Y.: Jonathan Cape and Harrison Smith, 1929, p.102-280.

6. Kon , I. S. 1997a The Sexual Culture in Russia. M.: OG.I. 464 p.

7. Makletsov A.V. Marriage and a family in the Soviet Russia.[Brak i sem'ya v Sovetskoi Rossii]. Ljubljana, 1937, p. 11-13.

8. Phillips Ch. Thomas. Feminism and family: historical and sociological analysis. M, 2002, p. 5. 
9. Reich W. The Sexual Revolution. Toward a Self-Regulating Character Structure. (Translated by Theresa Pol), Farrar, Straus and Girou, New York, 1974 (1986), p. 120-147.

10. Siegelbaum Lewis. H. Soviet State and Society between Revolutions, 1918-1929. Michigan State University. Cambridge University Press, 1992, p. 149-155.

11. Solomon S., The Red War on the Family. Copyright, 1922, by Samuel Solomon, Washington, D.C. Press of J.J. Little \& Ives Company, New York, U.S.A., p. 139-164.

12. Sorokin P. American sexual revolution. G.F. Voytenkova's translation, under the editorship of N.E. Markova. M, 2006, p. 14.

13. Stern M. and Stern A. Sex in the Soviet Union. Translated from the French by Marc.E. Heine. W.H. Allen. London. 1981, p. 28.

14. Strakhov A.M. Domestic Philosophy of the Sex and Love (Cultural and Philosophical Anthropology of the $19^{\text {th }}$ - beginning of the $20^{\text {th }}$ centuries). Available at: http: //www. dissercat.com/... filosofskaya-antropologiya-evolyutsii-obrazov-pol...( (accessed February 1, 2014).

\title{
Трансформация семейного законодательства
}

\section{в России в первой трети XX в.}

\author{
М.Д. Северьянова ${ }^{\text {, Л.У. Анисимова }}{ }^{\sigma}$ \\ ${ }^{a}$ Сибирский федеральный университет \\ Россия, 660041, Красноярск, пр. Свободный, 79 \\ ${ }^{\sigma}$ Российский государственньй сочииальньй университет \\ Филиал в г. Красноярске \\ Россия, 660041, Красноярск, ул. Можайского, 11
}

\begin{abstract}
В отечественной и зарубежной историографии дискутируется проблема, была ли сексуальная революиия в России в 1917-1922-е г2. и в СССР в 1923-1927 г2. В статье дается определение понятия «сексуальная революиия», рассматриваются противоположные точки зрения по проблеме, более того, проведен анализ законодательной базы, дискуссий периода 1920-х гг., современной литературы. В результате авторы пришли к выводу о том, что 1917-1927 г2. являются самостоятельным периодом в историографии проблемы. Законодательная база являлась либерализацией, эмансипацией женщин, однако женщины по-прежнему находились в экономической зависимости от мужчин. Многочисленные дискуссии, публикации тех лет частично отражали жизнь молодежи, особенно студенческой в крупных городах. В сельской местности семья и брак по-прежнему базировались на патриархальном семейном укладе.

Ключевые слова: законодательство, законодательная база семьи и брака, сексуальная револючия, эмансипачия женщин.
\end{abstract}

Научная специальность: 07.00.00-исторические науки. 